\title{
Comparison between the Grammar of Greek Sapphic and Tamil Seppal Songs
}

\author{
By D Pugazhendhi*
}

\begin{abstract}
Sapphic stanza is a peculiar poetic form in Greek literary world. It gives more important to the structure. This form was tried in many languages; but this form was grammatically explained only at the later period. Resemblance with this format is also seen in Tamil literary world, and the grammar book also belongs to the same period as that of Sapphic stanza. So the grammar that is explained in this Tamil grammar book is compared with the grammar of Sapphic stanza. The comparison is made in different perspectives such as the letter count, light and heavy syllables, formats of the syllable, sequences between two syllables, syllable formation in a line, the length of each line and the lyric. It highlights that the Greek Sapphic stanza seems to resemble one type of seppal songs which are mentioned in the grammar book. Comparing the Greek literature with the grammar book of same era will lead to better understanding and clarify the concepts that were misunderstood and spread by the later critics.
\end{abstract}

Keywords: comparison, grammar, Sapphic, seppal, structure.

\section{Introduction}

The Greek literature includes prose, poetry and dramas. In the Greek field of poetry comprises of various form of poems among which the Sappic stanza stands unique from others in its forms. This Sapphic stanza originated from the Greek poetess Sappho of Lesbos who lived sometime around 630 BC. It was written in vernacular form of Greek, the Lesbian-Aeolic dialect. In the 9th century A.D., the poems of Sappho disappeared. After that, only in the 16th century Sappho's poems regenerated in the literary world. Apart from all obstacles Sapphic poems and their stanzas still embrace a special place in the literary world.

Sappho in Greek Literary World

Sappho, the founder of the sapphic songs has some remarkable place in the literary world of the Greek. According to Thomas Wentworth Higginson, Atlantic Essays, 1871, Sappo is represented as "divinely tongued" or "spoke like gods."

"Out of a long list of Greek poetesses there were seven women who were, as a poem in the Greek Anthology says, "divinely tongued" or "spoke like gods." Of these Sappho was the admitted chief. Among the Greeks "the poet" meant Homer, and "the poetess" equally designated her. "There flourished in those days," said Strabo, writing a little before our era, "Sappho, a wondrous creature; for we know not any woman to have appeared, within recorded time, who was in the least to be compared with her in respect to poesy."1

\footnotetext{
*Associate Professor, Tamil Nadu Nandanam Government Arts College, India.

${ }^{1}$ Thomas Wentworth Higginson, Atlantic Essays, 1871.
} 
The distinctive feature in Sapphic form created interest for numerous poets from various languages to experiment and try this form. To mention some are the Greek poet Alcaeus, the Roman poet Catullus and Horace and the English poet Algernon Charles Swinburne. Since Sapphic stanza gives much importance to the form, it can very easily be categorised by the form. There are also evidences to show that this unique form created interest among poets to try-out them in different languages like the Greek, Latin, Polish, English and Chinese. Some of the evidences to show this are, one Greek sapphic poem, one among the three Sapphic Poems which was tried by the Chinese poetess of 19 century, two Latin sapphic songs, Wu Tsao, one sapphic poem in Polish and one sapphic song in English.

Figure 1. Sapphic Songs in Different Languages

GREEK SAPPHIC SONGS

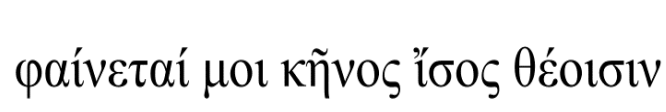

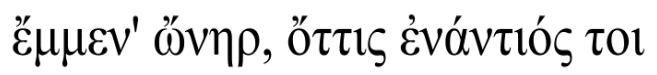

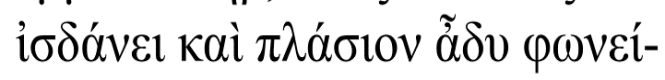

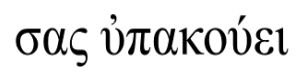

\section{严复曾在《天演论》讲到: 译事三难乃信、达、} 雅。“信”是指翻译要准确, “达”是指不拘泥于原 文, “雅”是指语句要得体适当。此句翻译可谓“信 达雅”具备矣。

Latin

Latin Rectius vives, Licini, neque altum Ille mi par esse deo videtur, semper urgendo neque, dum procella ille, si fas est, superare divos, qui sedens adversus identiden spectat et audit

litus iniquum.

$$
\begin{array}{lrr} 
& & \text { - Carmina, Od. 2.11 } \\
\text { Polish } & \text { Catullus } & \text { Horar }
\end{array}
$$

Nieszczęściu kwoli a swojej żałości, All the night sleep came not upon my eyeli Która mię prawie przejmuje do kości Shed not dew, nor shook nor unclosed a fec Lutnią i wdzięczny rym porzucić mu: Yet with lips shut close and with eyes of ir Ledwe nie duszę.

- Algernon Charles Swir

This Sapphic stanza is also found in the Tamil literature in a form very similar to this.

$$
\text { TAMIL }
$$

வாடை நலிய வடிக்கண்ணாள் தோள்நசைஇ

ஓடை மழகளிற்றான் உள்ளான்கொல் - கோடல்

முகையோடு அலமர முற்றுஎரி போல்பொங்கிப்

பகையோடு பாசறை உளான்.

This Tamil poetic form has a very specific name called the Seppal songs. The Tamil word Seppal also has phonetic resemblance with the Greek word Sapphic. It is also called as venba (literal meaning white stanza means to represent purity) in 
Tamil, meaning that this form is unadulterated and pure which means that this form does not allow even a tiny piece of other forms be mixed with it. So there is a necessity to compare the grammar of these forms of two different languages that are spoken by people of geographically far-off places.

\section{The Grammar of Greek Sapphic Stanza}

The Sapphic poems are related with the music. There was no evidence of any grammar or linguistic book or rules with which one could understand the grammar of the Sapphic stanza found available that belonged to the same era. In this regard, a Dictionary of Greek and Roman Antiquities that belonged to 1890 explains the problems behind this issue.

"The existing remains of ancient music consist of three "hymns," none of them probably earlier than the middle of the second century A.D., and a few fragments of instrumental music (apparently of the nature of exercises) preserved by an unknown writer of uncertain date [see MUSICA]. These, though they furnish some important data, are yet too fragmentary and too late to throw much light on the rhythms of the classical period of Greek music. Of the writers on rhythm whose works have been at all preserved, the first in order of time and importance is Aristoxenus (fourth century B.C.). Though he lived more than a century later than the time at which Greek poetry and music attained their highest development, he was still thoroughly acquainted with the music of that time; but, unfortunately, his rhythmical works are preserved only in a fragmentary condition. The writings of later theorists are chiefly valuable in so far as they are based on Aristoxenus."2

The grammar related with Sappho songs which existed in 630 BC., was available only in $400 \mathrm{BC}$., through Aristoxenus; but his explanation was only about the Greek music. Though it is related with the music in poems, it does not deal with the poem in totality. So, there is a need to explore for a grammarian who has mastery with only the poems that can be sung with music. Here the words of Plato shall be considered.

$[400 \beta]$

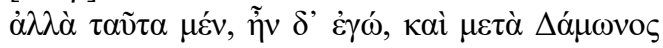

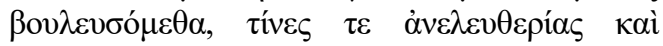

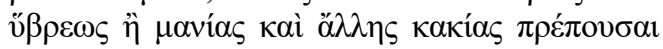

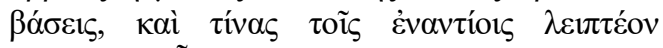

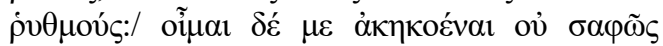

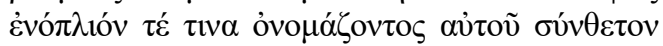

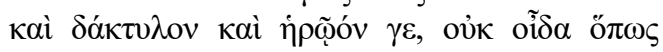

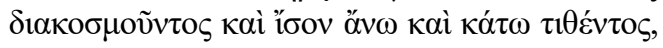

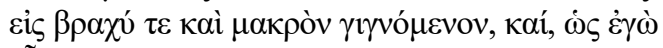

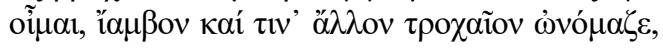
$\mu \eta ́ \kappa \eta ~ \delta \grave{\varepsilon ~ \kappa \alpha i ̀ . . . . ~}$ [400b]

"Well," said I, "on this point we will take counsel with Damon,1 too, as to which are the feet appropriate to illiberality, and insolence or madness or other evils, and what rhythms we must leave for their opposites; and I believe I have heard him obscurely speaking of a foot that he called the enoplios, a composite foot, and a dactyl and an heroic foot, which he arranged, I know not how, to be equal up and down in the interchange of long and short and unless I am mistaken he used the term iambic, and there was another foot that he called the trochaic, ${ }^{3}$

\footnotetext{
${ }^{2}$ Rhythmica, A Dictionary of Greek and Roman Antiquities (1890).

${ }^{3}$ Plato, Republic.
} 


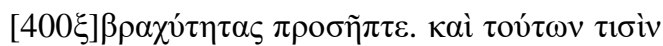

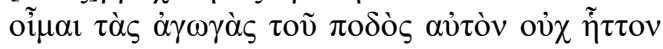

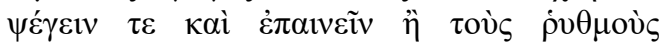

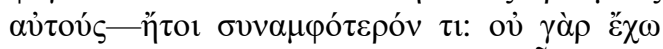

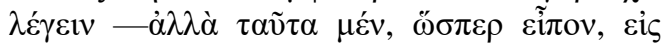

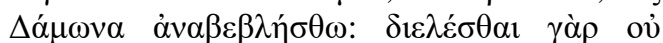

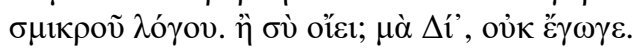

[400c] and he added the quantities long and short. And in some of these, I believe, he censured and commended the tempo of the foot no less than the rhythm itself, or else some combination of the two; I can't say; but, as I said, let this matter be postponed for Damon's consideration. For to determine the truth of these would require no little discourse. Do you think otherwise?" "No, by heaven, I do not." 4

So, Plato, who lived around $428 \mathrm{BC}$, has done research in many fields did not get into this form since this required much discourse as explained by himself.

Thus, there was difficulty in searching the data related with poems sung with music as in the case of Sapphic songs sung during this era. If it is not available in Greek language then it is to be searched in some other languages which belonged to the same era. In this connection, the notions mentioned by Greek Geographer Strabo in his work called Geographica which belonged to 7 BC., seeks attention and so, may be discussed in detail.

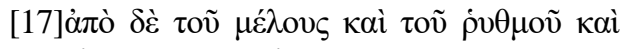

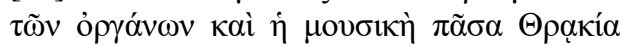

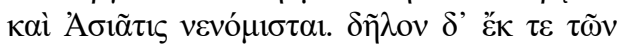

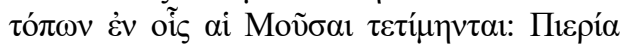

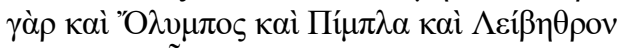

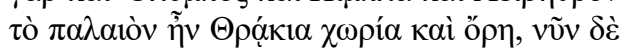

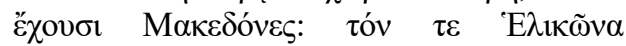

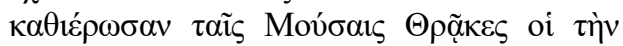

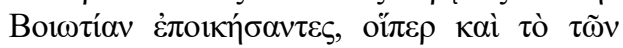

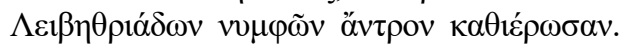

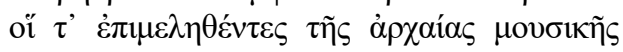

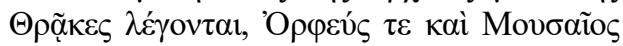

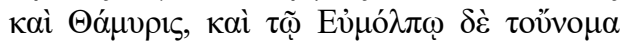

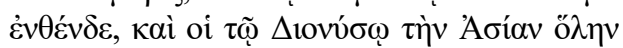

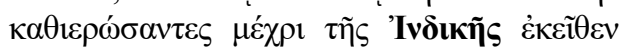

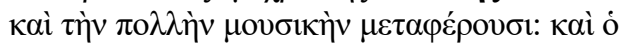

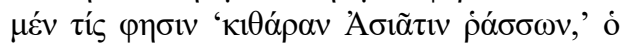
$\delta \dot{\varepsilon} \tau o u ̀ \varsigma ~ \alpha u ̉ \lambda o u ̀ \varsigma ~ B \varepsilon \rho \varepsilon \kappa v v \tau i ́ o v \varsigma ~ \kappa \alpha \lambda \varepsilon \tilde{~} \kappa \alpha \grave{~}$

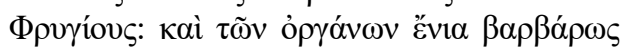

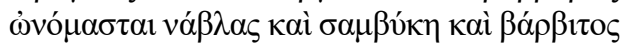

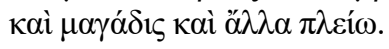

From its melody and rhythm and instruments, all Thracian music has been considered to be Asiatic. And this is clear, first, from the places where the Muses have been worshipped, for Pieria and Olympus and Pimpla and Leibethrum were in ancient times Thracian places and mountains, though they are now held by the Macedonians; and again, Helicon was consecrated to the Muses by the Thracians who settled in Boeotia, the same who consecrated the cave of the nymphs called Leibethrides. And again, those who devoted their attention to the music of early times are called Thracians, I mean Orpheus, Musaeus, and Thamyris; and Eumolpus too, got his name from there. And those writers who have consecrated the whole of Asia, as far as India, to Dionysus, derive the greater part of music from there. And one writer says, "striking the Asiatic cithara"; another calls flutes "Berecyntian" and "Phrygian"; and some of the instruments have been called by barbarian names, "nablas," "sambyce," "barbitos," "magadis," and several others. 5

This shows that during the period of Dionysus, the Indian music, musicians and the musical instruments got familiarised in the Greek land in the name of Thracians. Twentieth century classical scholar White also attested the relationship between Sapphic stanza and India.

'Thus, by the early twentieth century, some classical scholars were looking back to the Indo-European roots of Sapphic meter. In 1909 John Williams White

\footnotetext{
${ }^{4}$ Plato, Republic.

${ }^{5}$ Sec.17, Chap. 3, Book 10, The Geography of Strabo.
} 
published "The Origin and Form of Aeolic Verse" .... White suggests these syllables were regulated into patterns by a "rhythmicizing instinct that gave melodic form to the second half of the primitive dimeter first in India," and then among the Ionian poets," and then their brothers, who in course of time made their way and settled Aeolis and metrized differently." 6

So, from the words of Strabo and John Williams White, the data related with Sapphic songs may be available in Asian languages, in particular, in Indian languages. One such Indian Language is Tamil.

\section{Tamil Language}

Like that of the Greek language, Tamil language also has very vast literary heritage. Further, the Tamil language has separate grammatical tradition. The first, the grammar book available in Tamil language finds its place earlier than $600 \mathrm{BC}$. The book is called Tholkappiam. Thol means 'ancient'. Kappiam means book or grammar. This book explains the grammar of the language and the theme of the literature with linguistics approach. In the language point of view, it deals with mora, syllable, structure of words, formation of words in a line and formation of one poem by several lines. In all these concepts, it also deliberates the grammar of seppal songs, which has resemblance in its overall view with that of Sapphic stanza. So, there exists a space to compare the concepts of Tamil Tholkappiam with the Sapphic stanza. To understand the stanza, knowledge of letters, mora, syllable, feet and many more related with the formation of it are very important.

\section{Letters}

The Greek Alphabets consist of 24 letters. The vowels are $\alpha, \varepsilon, \eta, \imath, o, \omega, v$. The remaining letters are consonants. And the phoneme /w/ which was in the Aeolic dialect of Sappho, at the fore part of the words disappeared in the presentday Greek. Besides, in Greek language the vowels $\varepsilon$ and o are always short, whereas $\eta$ and $\omega$ are always long. It is understood that $\eta[H], \omega[\Omega]$ are long vowels for the short vowels $\varepsilon$, o respectively. The vowels $\alpha, 1$, and $v$, are either short or long depending upon the place of its occurrence in a word. In case if they happen to be long a line is drawn above it like the ones shown here $\bar{i}, \bar{v}$.

\section{$\underline{\text { Tamil }}$}

Tamil language has three letter system consists of 247 letters. Letters exists separately for vowels, consonants and vowel consonant. In vowels there are separate letters for short and long. Here the comparison between the letter system seem two languages is tabulated.

\footnotetext{
${ }^{6}$ Yopie Prins (2019)
} 
Table 1. Comparison of Letter System

\begin{tabular}{|l|c|}
\hline Greek & Tamil \\
\hline 24 letters & 247 letters \\
\hline $\begin{array}{l}\text { Some vowel may be pronounced either } \\
\text { short or long }\end{array}$ & \begin{tabular}{l} 
Separate letters for short and long vowels \\
\hline Letters for vowels and consonant
\end{tabular} \\
$\begin{array}{c}\text { Letters for vowels, consonants and vowel } \\
\text { consonants. }\end{array}$ \\
\hline
\end{tabular}

Here in Tamil the vowel consonant contribute for the difference in the letter count. For universal understanding, let us take English letters which are equal to Greek letters.

\section{Letter Count}

Normally a, b, c, d and e are counted as five single letters and so, 'ba' is counted as two letters and 'de' is counted as two letters.

\section{$\underline{\text { Tamil Tholkappiam }}$}

In Tamil language, consonant ' $b$ ' is written as ' $\dot{\boldsymbol{L}}$ ' and vowel 'e' is written as ' இ'; but 'be' is written as 'பी' So, in European language 'be' = two letters and in Tamil language 'be' $=\boldsymbol{\Delta}=$ one letter.

\section{Mora}

Mora is the basic unit of time for the verse. In Greek verse, a short syllable is a single mora and a long is two. For universal understanding, the English phonemes of consonants and short vowels like a, b, c, d, e, f and so on have single mora whereas long vowels like aa, ee, and so on have two mora; but it is not that very simple to understand as it is mentioned. The difficulty can be felt in its time measurement as illustrated by the ancient Greek scholars.

"Aristoxenus also speaks of a quantity which is intermediate between the normal long and the normal short, which, if the short syllable be taken as $=1$,

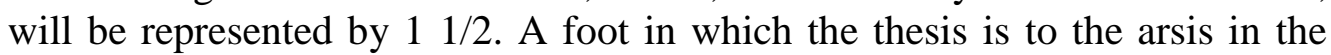

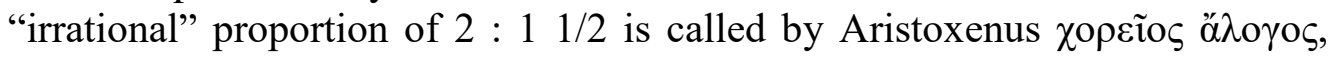
and is probably to be identified with the spondee, which is often found in trochaic and iambic metres in the even and odd places respectively. If this be so, the long syllable in the arsis of trochaic and iambic feet is of abnormal

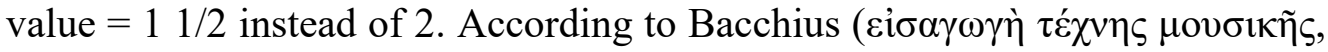

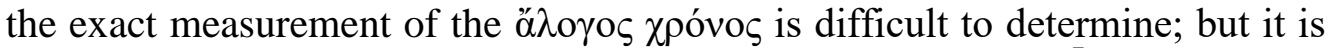
shorter than the normal long, and longer than the normal short."7

This definition, in Greek, that is related with music, is difficult and obscure to understand for the poetic persons. The way in which it is explained in Tamil Tholkappiam, purely as literature makes one to understand it easily.

\footnotetext{
${ }^{7}$ Aristoxenus Rhythmica, A Dictionary of Greek and Roman Antiquities (1890).
} 


\section{$\underline{\text { Tamil Tholkappiam }}$}

In Tamil Tholkappiam, Mora is called as 'Maathirai'. The measurement of Maathirai is to some extent related with Mora in Greek. In addition to that, there is a separate consonant which has only $1 / 2$ mora in Tamil which ascertains that a separate consonant does not count as neither a short nor a long syllable. According to Tholkappiam, the short and long syllable are only related with vowels and vowel-consonant (in Tamil it is called as uirmai yeizhuthukal) combined letters.

Therefore, for better understanding it is explained separately for consonants and vowels since Greek and English language do not have 'vowel- consonant' combined letters. For this, first consider the vowels, 'a, e, i, o, u' that has each 1 mora and when two vowels are combined like that of 'aa, ee, ii, oo, uu' two short vowels (though two short vowels cannot be equated with one long vowel; but in this place they are joined only to symbolise the representation of long vowel) each has 2 mora. These are same in Tamil. Further, single consonant say b, c, d,...has $1 / 2$ mora [in the places like $\mathbf{b}$ in crab, $\mathbf{c}$ in lock and $\mathbf{d}$ in God] in Tamil and that of consonant-vowel joined letters like that of ba, ca, da,... has 1 mora in Tamil [Here, though $b$ has $1 / 2$ mora, when it is combined with vowel the consonant loses its mora and retains only the mora of vowel. This rule shall also be applied to long vowels like baa, caa, daa,...has 2 mora. So the definition given by Tamil Tholkappiam is not obscure and unambiguous.

\section{Syllables}

The knowledge of syllable is important in understanding of the poetic stanzas. It is a unit of speech, either a whole word or parts by which a word can be separated with a pause. There are certain rules for making the pause in a word which are related with syllable weight.

\section{$\underline{\text { Syllable Weight }}$}

In Ancient Greek, syllables were divided into two types. They are called as longum and brevis. For universal understanding let us denote the longum, as a heavy syllable and the brevis, as a light syllable.

\section{Light Syllable}

Light syllable is the small unit of a word. The light syllable is associated with certain rules.

Rule 1: A syllable ending in a short vowel without consonant

Example 1: ớc /ă:.te:/

$$
\text { Atom /'a.təm/ }
$$

Here the syllable $\alpha$ and A are short vowels. After that a pause has occurred. The occurrence of a short vowels followed by pause make it to be treated as separate syllables. As they are Vowels it is denoted using the first letter as ' $\mathrm{V}$ '. 
Rule 2: A syllable ending in a short vowel along with a consonant

Example 2: $\lambda \dot{\varepsilon} \gamma \omega /$ lé.go:/ $\rightarrow$ /'le. yo/ $\rightarrow$ /'le.yo/

Penetrate /'pe.nit.eit/

Here the syllable $\lambda \dot{\varepsilon}$ and Pe are consonants with a short vowels. After that there is a pause. The short vowels up to the pause together are treated as one separate syllable which is in the format of combination of Consonant and Vowel, and so it is denoted as ' $\mathrm{CV}$ '. The Greek grammarians called these light syllables as $\theta \varepsilon \dot{\sigma \varepsilon} 1 \mu \alpha \kappa \rho \alpha ́$. For easy understanding, the syllables that are light weight are denoted by the symbol

\section{Heavy Syllable}

Syllables longer than the light syllables are called as heavy syllables. These are connected with some specific set of rules.

Rule 1: A syllable ending with a long vowel and without a consonant

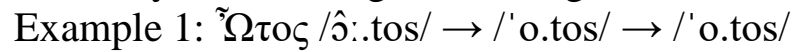

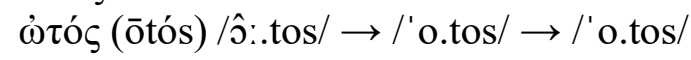

eel èl

Here the syllables ' $\Omega$, $\dot{\omega}$, ee occur as long vowels. After that there is an occurrence of a pause. So, the long vowel up to the pause are treated as one separate syllable which falls in Vowel Vowel format and is denoted as ' $\mathrm{VV}$ '.

Rule 2: A syllable ending in a long vowel along with a consonant

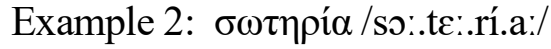

\section{Road - rōd/səod/}

Here the syllables $\sigma \omega$, Ro occur as long vowels with consonant. After if there is a pause and hence up to the pause it is treated as one separate syllable that is in the format of Consonant Vowel Vowel and which is denoted as 'CVV'.

Rule 3: A short vowel followed by one or more consonants make a pause. This type of syllable is called as closed syllable. The end of the consonant is called as coda.

Example: $\alpha \dot{\alpha} v \delta \rho \tilde{v} v /$ an.drô:n/

Here the syllables $\dot{\alpha} v \delta$, occur as a short vowel, followed by two consonants. It makes a pause and become separate syllable. They are in the format of Vowel Consonant. So it is denoted as 'VC'. In classical Greek, this format is considered as heavy; but in some languages it is considered as light syllable.

Though $\rho$ being a third consonant it is not joined with the previous syllable because it is followed by a vowel. Hence $\rho$ joins with the vowel that follows it to form another new syllable.

Rule 4: A consonant with a vowel followed by one or more consonants. It makes a pause and it is treated as one separate syllable. They are in the format of Consonant Vowel Consonant. So it is denoted as 'CVC'. This is also called as closed syllable. The end of the consonant is called coda.

Examples: $\pi \varepsilon ́ \lambda \tau \alpha \varsigma$, Current

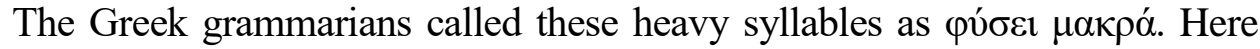
these heavy syllables are denoted by the symbol 
In moraic theory, heavy syllables are analysed as containing two morae, and the light syllables have one mora; but the Greek scholars themselves raise a doubt in this explanation.

"The writers on metre (i.e. that species of rhythm which is exhibited in the measurement of syllables) are all of late date, and are for that reason to some extent untrustworthy."

From this, it is clear that there exist certain difficulties like, the authors on metre (which is a species of rhythm) is out-dated and so it cannot be trusted and also the time gap between the poem and the researcher cannot be matched. This may be explained by the Tamil grammar book that prevailed during the same era called Tholkappiam.

\section{$\underline{\text { Tamil Tholkappiam }}$}

The light syllable form and the heavy syllable form were also explained in Tamil Tholkappiam. The light syllable is called as 'Nēr asai' and the heavy syllable syllable. In ancient Greek it is denoted as 'ỗ $\sigma \mu \alpha$ ', in Latin 'āsthma', There are many rules related with 'Nēr asai' and 'Nerai asai'.

Table 1. Rules

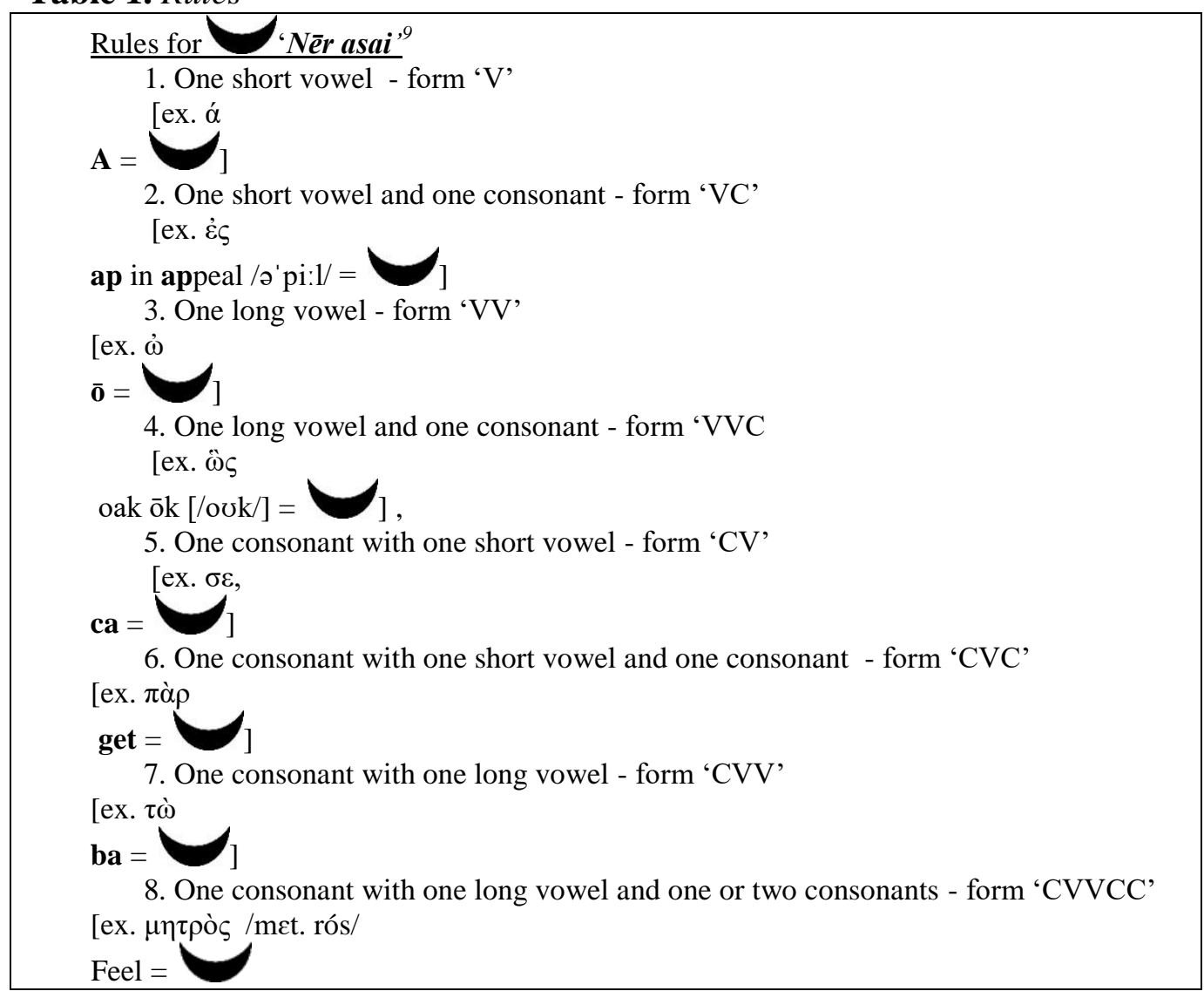

${ }^{8}$ Rhythmica, A Dictionary of Greek and Roman Antiquities (1890) .

${ }^{9}$ Tholkappiam, seiyulial - 1261 


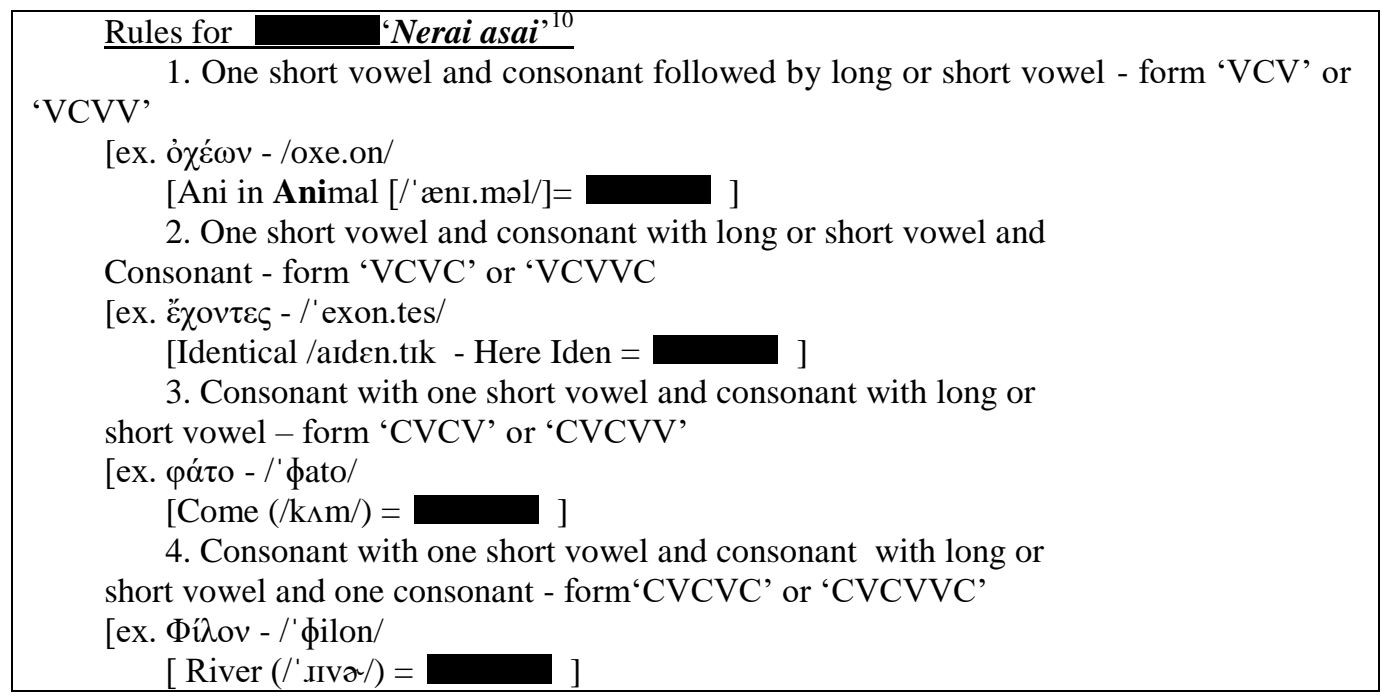

Thus the rules for both and are defined in Tamil Tholkappiam. Also, it is necessary to discuss, whether two join and make one for which the knowledge of division rules is important.

Table 3. Rules

Division rules

1. In a word if the first letter is a vowel and it is pronounced long, then it has to be treated as separate short syllable in the form of light weight be joined with the following letter to make it heavy weight

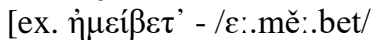

Here $\dot{\eta}$ is a long vowel. It itself is a separate syllable with light weight and also it won't join with the following $\mu \varepsilon i$ and be made heavy weight. Since this rule is applicable also for a word with consonant and a long vowel, for universal understanding the word wooden is taken and it has to be separated as Woo.den and here Woo becomes light weight syllable.

2. In a word if the first letter is a short vowel, it will not stand as a separate syllable if followed by a consonant and with short or long vowel then it should be joined together to make a long and heavy syllable in the form of

[ex. è $\lambda \alpha \alpha \alpha v$

Animal - [ Ani. mal]

Here $\dot{\varepsilon}$ and A are short vowels. The followings are $\lambda \alpha \dot{\alpha} \alpha$ for $\dot{\varepsilon}$ and ni for A. So $\dot{\varepsilon}$ and A won't make a light syllable ; but joining with the following letter like $\dot{\varepsilon} \lambda \alpha \dot{\alpha} \alpha$ and Ani to form a heavy syllable.

3. In a word if the first letter along with a vowel, which is pronounced either long or short and after that there is a consonant or more and is without any vowel, then all of the letters are joint together; but will make only a separate light syllable

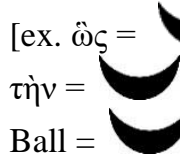

Here in the word ballpoint pen, the syllable ball don't get separated; but remains a single light syllable and also it is not joined with point to make a single syllable.

4. In a word if the first letter is a vowel which is pronounced short, it should be joined

\footnotetext{
${ }^{10}$ Tholkappiam, seiyulial - 1261

${ }^{11}$ Tholkappiam, seiyulial - 1261
} 
with the next letter followed by a vowel either long or short and after that there is one or more consonant without vowel, then all are jointly treated as separate mono syllable in the form of

[еx. 'O $\lambda \hat{\prime} \mu \pi \imath \alpha$ - 'O $\lambda \hat{\mu} \mu . \pi 1 \alpha$

Olimpia - Olim. pia

Here $\mathrm{O}$ is a short vowel so it joined with li and after that $\mathrm{m}$ occurs without vowel, so all are joined to make a only a single syllable with heavy weight.

Olim =

These are the important rules in the division of syllables. Here, the long pronunciation and the occurrence of a consonant without vowel play an important role in separating the syllables. To understand this in a better way, instead of taking different words as examples to explain the difference, it is better to take one word as an example just without considering its original meaning with the assumption that the long and short pronunciation should be separate phonemes. The phonetic symbol - above the letter denote the long pronunciation. The line drawn below represents the join of syllables. The different combination of syllables are explained in an imaginary way only for clarifying the rules.

Figure 2. Imaginary Example

Manager $=\{[\mathrm{Ma}][\mathrm{na}][$ ger $]\}$

1. $\{[\mathrm{Ma}][\mathrm{na}][\mathrm{ger}]\}=\left\{\begin{array}{l}\text { Mana }- \text { Two short vowels with } \\ \text { consonants joined }\end{array}\right.$

2. $\{[\mathrm{Ma}][\overline{\mathrm{na}}][\mathrm{ger}]\}=\{$ Mana - one short, one long

2. $\{[\mathrm{Ma}][\overline{\mathrm{na}}][\mathrm{ger}]\}=\left\{\begin{array}{l}\text { Mana }- \text { one short, one long } \\ \text { vowels with consonants joined }\end{array}\right.$

3. $\{[\overline{\mathrm{Ma}}] \mathrm{Ma}-$ long - separated,

3. $\{[\overline{\mathrm{Ma}}][\mathrm{na}][\mathrm{ger}]\}=\smile \smile\left\{\begin{array}{l}\text { nager -Two short vowels with } \\ \text { consonants joined }\end{array}\right.$

4. $\{[\overline{\mathrm{M}} \mathrm{a}][\mathrm{na}][\overline{\mathrm{ger}}]\}=\bigcup\{\mathrm{Ma}-$ long - separated,

4. $\{[\overline{\mathrm{Ma}}][\mathrm{na}][\overline{\mathrm{ger}}]\}=\smile\left\{\begin{array}{l}\text { nager }- \text { one short, one long } \\ \text { vowels with consonants joined }\end{array}\right.$

5. $\{[\overline{\mathrm{Ma}}][\overline{\mathrm{na}}][\overline{\mathrm{ger}}]\}=\smile \smile\{$ All long - separated

Thus the rules used for the separation of syllables in Tamil are explained by considering the English word 'manager'. Here, if the word manager is pronounced in different ways that gives different assumed meanings, then long and short pronunciations will become different phonemes, and so the same word can get different syllable forms. Hence, this is very important because poets join the words as per the rules; but without this knowledge if it is dealt then it won't serve the actual purpose.

For example, $\underbrace{\text { கற்க கசடற }}$ is the phrase represented with the forms as shown below; but without the awareness of this form and for the purpose of easy reading and understanding, the second form of the word sometimes gets split into two forms as கற்க கசடு அற . This may seem to be very simple; but it very badly affects the poetic forms. It is to be noted here that 
seppal poetic structure follows very strict rules. Without knowing the rules of the structure, if anyone handles it, then it loses its originality. So the knowledge of syllabic forms is important.

The rules in Tamil and Greek are compared here. As per the rules given in Tholkappiam in the mono syllabic format the number of the light syllables are more when compared with that of the Greek rules. Besides, the rules for the mono syllabic heavy syllables which are mentioned in Tholkappiam are treated as disyllabic according to the Greek rules.

Table 4. Tamil and Greek Syllabic Format

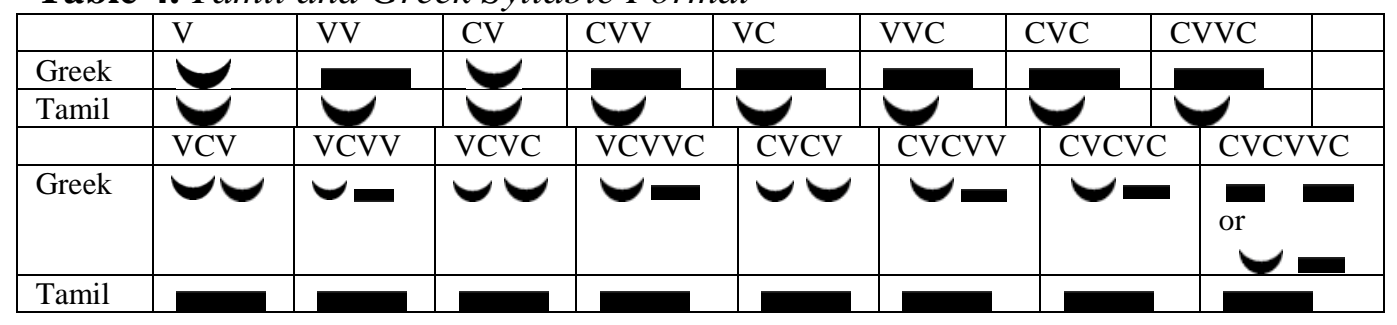

In this way the rules for light and heavy syllables are more in Tholkappiam.

Table 5. Tamil and Greek $C$ and $V$ format

Light Syllable

\begin{tabular}{|c|c|}
\hline Greek & Tamil \\
\hline $\mathrm{V}$ & $\mathrm{V}$ \\
\hline $\mathrm{CV}$ & $\mathrm{CV}$ \\
\hline & CVC \\
\hline & CVV \\
\hline & CVVC \\
\hline
\end{tabular}

Heavy Syllable

\begin{tabular}{|c|c|}
\hline Greek & Tamil \\
\hline VV & \\
\hline CVC & \\
\hline CVV & CVCV \\
\hline & CVCVV \\
\hline & CVCVC \\
\hline & CVCVVC \\
\hline
\end{tabular}

In this way the Greek and Tamil rules have a lot of differences in the syllable representation.

\section{Greek Feet}

The combination of short and long syllables makes mono-syllabic, di-syllabic and tri-syllabic forms. Tetra-syllabic form is also possible; but normally up to three syllabic forms are only used in poetry.

Aristotle, who lived in the $335 \mathrm{BC}$ in his work called Poetics, mentions the convention behind the Greek system of form. 


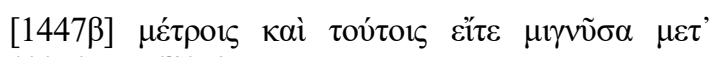

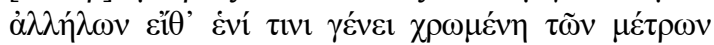

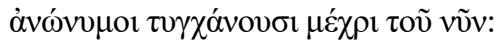

[1447b] [1] either in one kind of metre or combining several, happens up to the present day to have no name. ${ }^{12}$

After that, Greek scholars coined the technical terms for the different types of syllable forms. Even now in Greek language there are words to denote these

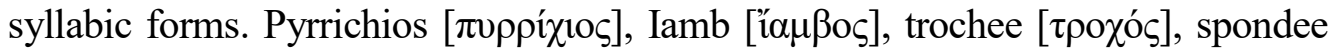

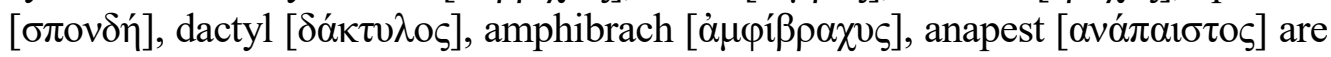
some of the poetic words for these syllabic forms.

Among these forms, the Sapphic stanza uses only trochee [ $\tau \rho o \chi o ́ s]$ and

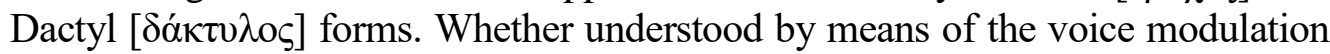
or any other means, it does not compromise on the strict usage of these syllables.

Table 6. Types of Syllable and their Structures

\begin{tabular}{|c|c|c|c|}
\hline Greek & Pronunciation & Meaning & Structure \\
\hline$\pi v \rho \rho i ́ \chi 10 \varsigma$ & $\begin{array}{l}\text { pyrrichios, } \\
\text { pyrrhus, } \\
\text { dibrach }\end{array}$ & & \\
\hline ' $\alpha \mu \beta$ o & Iamb & $\begin{array}{l}\text { Greek minor goddess of } \\
\text { verse }\end{array}$ & \\
\hline 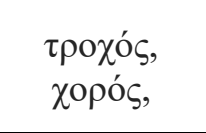 & $\begin{array}{l}\text { trochee, } \\
\text { choree, } \\
\text { choreus }\end{array}$ & $\begin{array}{l}\text { Wheel or "rolling" } \\
\text { rhythm }\end{array}$ & \\
\hline$\sigma \pi 0 v \delta \eta ́$, & Spondee & libation & \\
\hline & Tribrach & & \\
\hline \multirow[t]{2}{*}{$\delta \alpha ́ \kappa \tau v \lambda \circ \varsigma$} & $\begin{array}{l}\text { Dactyl } \\
\text { finger }\end{array}$ & & \\
\hline & Antibacchius & & \\
\hline$\dot{\alpha} \mu \varphi \hat{\prime} \beta \rho \alpha \chi \nu \varsigma$, & Amphibrach & "short on both sides". & \\
\hline \multirow[t]{4}{*}{$\alpha v \alpha ́ \pi \alpha 1 \sigma \tau о \zeta}$, & $\begin{array}{c}\text { anapest, } \\
\text { antidactylus }\end{array}$ & $\begin{array}{c}\text { "struck back" (a dactyl } \\
\text { reversed) }\end{array}$ & \\
\hline & Bacchius & & \\
\hline & $\begin{array}{c}\text { cretic, } \\
\text { amphimacer }\end{array}$ & & \\
\hline & Molossus & & \\
\hline
\end{tabular}

Like that of the Greek, Tamil language also has the mono-syllabic forms, disyllabic forms and tri-syllabic forms. It also has separate poetic words to denote these syllables. These words are not to be considered as mere words being used in the language; but here words are constructed by means of a formula and it is seen

\footnotetext{
${ }^{12}$ Aristotle, Poetics,
} 
inbuilt with its structure having the respective syllabic format. For this specific reason they find a place of mention here with its Greek equivalents.

\section{Tamil Tholkappiam}

Table 7. Names of Greek and Tamil Syllable and their Structures

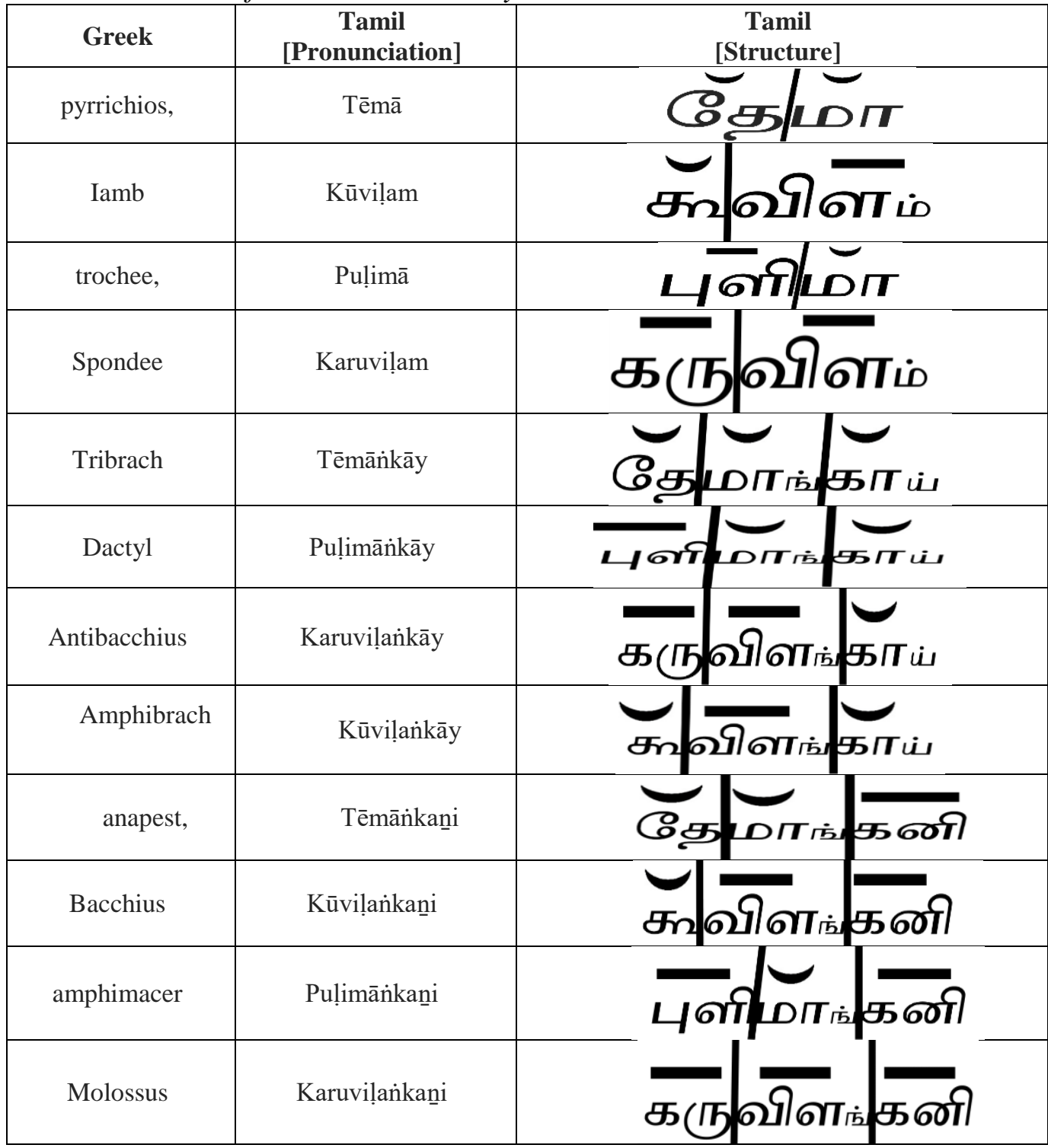

The mentioned words are some of the poetic words to represent the syllabic forms. In these formulas, the letters which have dot on top of it are figured small because they are pure consonant sounds, and they are not counted in the syllable; but makes a pause in the syllable. In addition to all, the grammarians coined the poetic technical words by using the name of trees.

Among these general forms, Tamil seppal songs have all the two syllable forms of pyrrichios, trochee, iamb and spondee and in three syllable forms, it has all that which ends with 
Table 8. Comparison of Syllable in Greek and Tamil Poems

\begin{tabular}{|c|c|}
\hline Greek Sapphic & Tamil Seppal \\
\hline \multicolumn{2}{|l|}{ Two Syllables } \\
\hline \multirow[t]{4}{*}{ trochee } & trochee $[\tau \rho o \chi o ́ \varsigma]$ \\
\hline & pyrrichios [ $\pi v \rho \rho i ́ \chi 10 \varsigma]$ \\
\hline & iamb [í $\alpha \mu \beta o \varsigma]$ \\
\hline & spondee [ $\sigma \pi \mathrm{o} \sigma \delta \eta \dot{]}]$ \\
\hline \multicolumn{2}{|l|}{ Three syllables } \\
\hline \multirow[t]{4}{*}{ dactyl } & 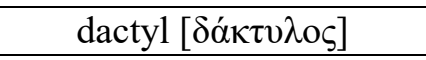 \\
\hline & tribrach \\
\hline & antibacchius \\
\hline & 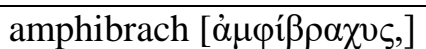 \\
\hline
\end{tabular}

In two syllabic forms, both the Greek Sapphic and the Tamil seppal have trochee forms. In addition to that the Tamil seppal also has all the two syllabic forms. The same thing is seen in the three syllabic format that is both the Greek Sapphic and the Tamil seppal have the dactyl form. Still more the Tamil seppal has all the three syllabic forms which end with and both the Greek and the Tamil do not use the three syllabic forms which end with $\longrightarrow$. Though the boundaries of the forms may be seen broad in the Tamil when compared with that of the Greek, they both strictly adhere not to use any other forms than that prescribed in its unique structure.

But how these trochees and dactyls found in lyrics forms are related with rhythmic is a big question that exists in front of us.

"There is, however, a class of metres of very frequent occurrence in which feet of different metrical value, viz. trochees and dactyls (or iambics and

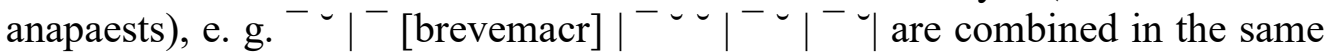
$\kappa \tilde{\omega} \lambda \mathrm{ov}$. These metres are called "mixed" ( $\mu 1 \kappa \tau \alpha \dot{\alpha})$, or logaoedic $(\lambda \circ \gamma \alpha 01 \delta 1 \kappa \alpha ́)$. The latter name was probably given to these metres because, from their apparent irregularity, they seemed to be intermediate between prose ( $\lambda$ ó $\gamma \circ$ ) and poetry or song (áo1 $\left.\delta \eta^{\prime}\right)$. The explanation of this union of trochee and dactyl, and the rhythmical relation between them, is uncertain," 13

So, the thought that the union of trochee and dactyl itself makes rhythmic poem which is seen obscure even to Greek scholars is to be explored. That is this format alone does not suffice the existence of rhyme; but there is yet another important factor in making of it. That factor lies in the sequence that is followed in the usage of trochee and dactyl in constructing a line.

\section{Word Sequence}

In poetic stanzas, the sequence of the word formation is an important feature. The relation between the concluding syllable of the existing word and the opening syllable of the word that follow the existing one are taken into account.

\footnotetext{
${ }^{13}$ Rhythmica, A Dictionary of Greek and Roman Antiquities (1890)
} 
Figure 3. Structure of Word Sequences
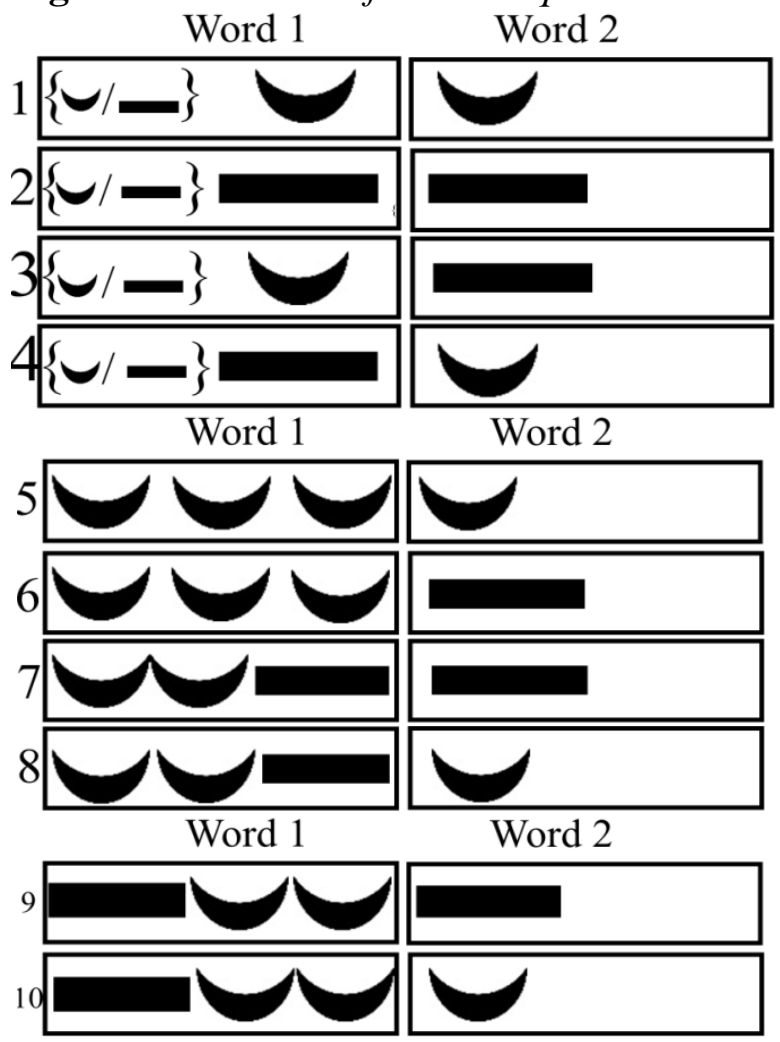

Tamil Tholkappiam tells about many form of sequences using syllables, The grammatical name of these structures is called 'thalai'. There are separate names for each of these that are mentioned in Tholkappiam. ${ }^{14}$ Among these sequences, the sequence which is numbered 3 is only followed in Sapphic stanza.

Figure 4. Sequence of Words in Sapphic Stanza

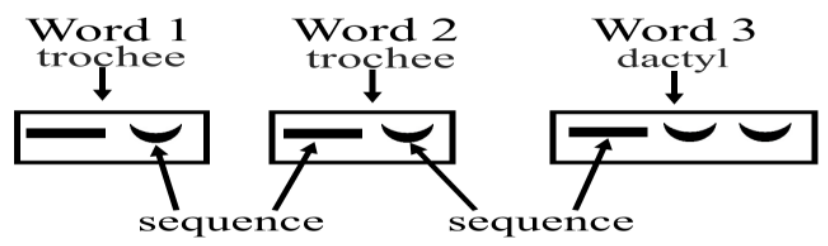

Here it can be observed that the existing word ends with short form, and the next word that follows the existing word starts with long form. This way of grouping of opposite forms is found both in the two-syllabic and three syllabic format in Sapphic stanza. In two syllabic format, the Tamil seppal songs follows the same way of grouping of opposite forms as that of Greek. In addition to this, Tamil seppal songs also have sequences made by joining of existing word ending with long form, and the following next word beginning with short form. Whereas in three syllabic format, the making of the sequence is done by grouping the

\footnotetext{
${ }^{14}$ Tholkappiam, seiyulial, $1311-1317$
} 
existing word which ends with short form, and the succeeding word also begins with the same short form. From the above, it is clear that the Tamil seppal songs follow two more ${ }^{15}$ forms than that is followed in Greek.

Table 9. Comparison of Word Sequence in Greek and Tamil Poems

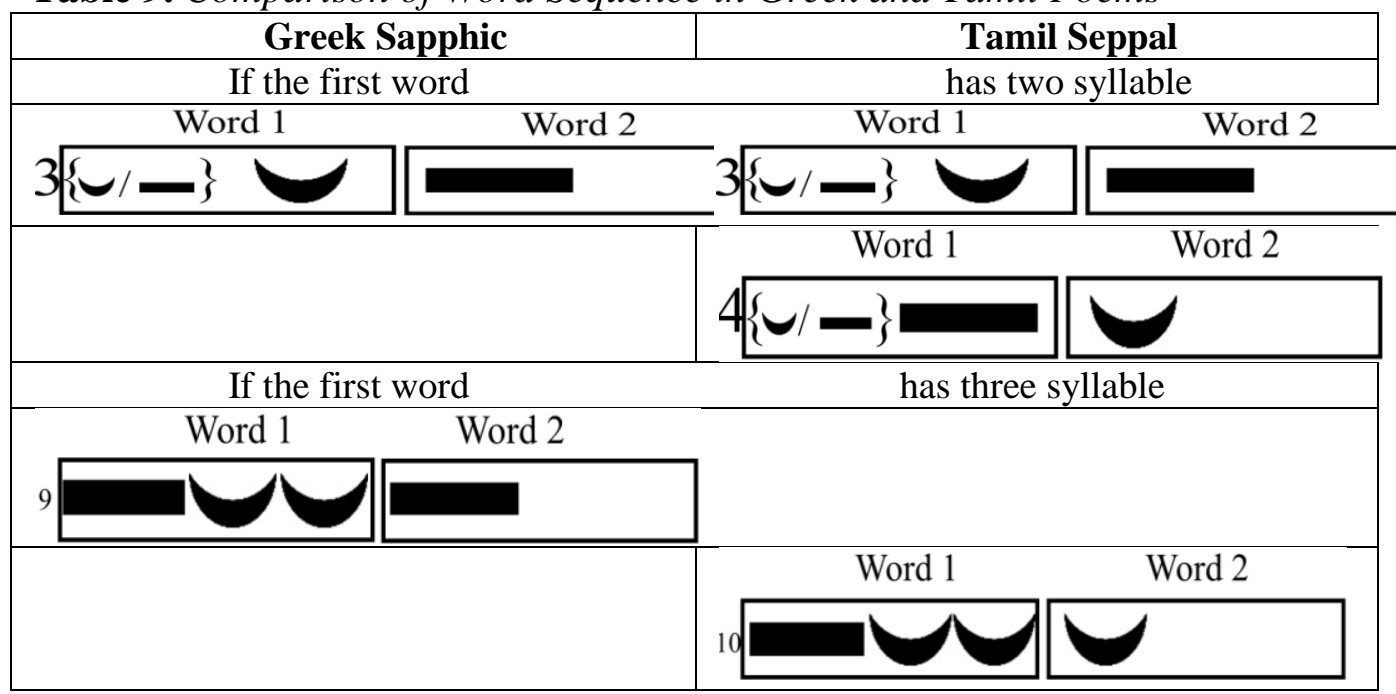

So in the word formation of the Greek Sapphic and the Tamil seppal songs, there are some similarities and differences. Both of them follow the rule given in the number 3 format. In the Greek the same rule of two syllabic formation is continued in three syllabic formation also; but in the Tamil language it is not the same. With these formats of syllables, the Greek Sapphic and Tamil seppal songs construct the line format.

\section{Syllable or Letters in a Line}

Syllable or letters in a line is also a very important factor in the harmony of the lyrics in the poems. The first three lines of the Sapphic stanza have totally 11 syllables and the forth or the last line have 5 syllables. This is a strict rule to be followed in the making of Sapphic stanza.

\section{$\underline{\text { Tamil Tholkappiam }}$}

Tamil Tholkappiam explains more than 5 types of line formation. ${ }^{16}$ Unlike in the Greek, all the lines format have poetic names that are mentioned in the Tamil Tholkappiam.

\footnotetext{
${ }^{15}$ Tholkappiam, seiyulial, 1315

${ }^{16}$ Tholkappiam, seiyulial, $1292-1297$
} 
Table 10. Types of Lines and their Names

\begin{tabular}{|l|c|c|}
\hline S.No. & Letter count in a line & Name of the line \\
\hline 1. & $4-6$ & Kural Adi \\
\hline 2. & $7-9$ & Sinth Adi \\
\hline 3. & $10-14$ & Alavu Adi \\
\hline 4 & $15-17$ & Neadil Adi \\
\hline 5. & $18-20$ & Kazhi Neadil Adi \\
\hline
\end{tabular}

Here the line is denoted as 'Adi'. In these line formats, one type of Tamil seppal songs make use of 'Alavu Adi' in the first three lines and 'Sinth Adi' in the last line. So, here it is observed that the last (fourth) line is shorter than that of the remaining three lines. This structure is similar to that of the Greek Sapphic stanza; but here one more thing is to be noted. Tamil Tholkappiam talks about 10-14 letter count in a line, whereas the Greek Sapphic talks about 11 syllable count in a line. Here, it is essential to know the relation between the Tamil letter count and the Greek syllabic count.

\section{$\underline{\text { Relation of the Tamil letter and the Greek syllable }}$}

It is known that the Tamil language has a separate letter type called vowelconsonant (uir-mei yezhuthu) and also separate letters for short and long vowels. Since, joining of two short syllable cannot make one long syllable in music, in the same way, two short pronunciations won't make one long pronunciation. So it has separate letters for short and long vowels. Also short and long pronunciations are separate phonemes in Tamil language. Let us consider for example, the three letters 'bee', which is represented as one letter in Tamil.

\section{Figure 5. Letter Counting}

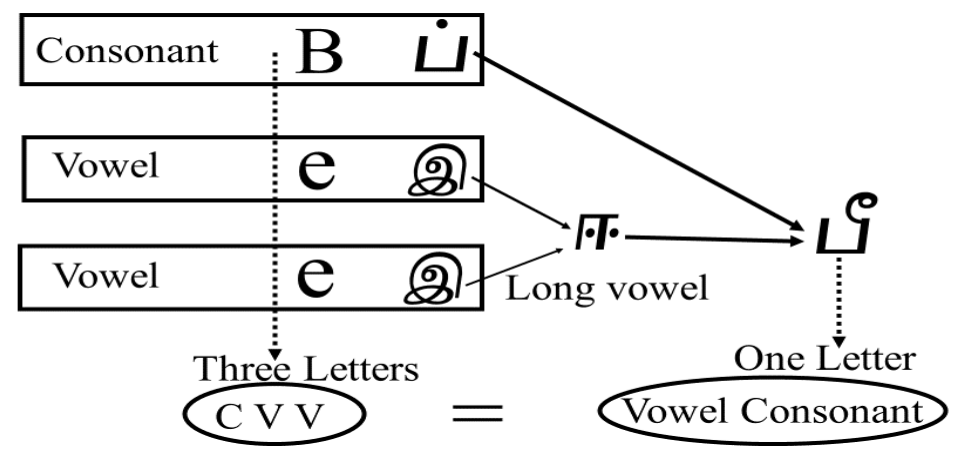

In this way, two to three letters used in the Greek is represented as one letter in the Tamil. Also, two to three letters of the Tamil make a syllable in the Greek. So the rule of $10-14$ letters (which is called as Alavu Adi) in a line of the Tamil seppal song is more or less equal to 11 syllables of the Greek Sapphic songs. In the same way last line of $7-9$ letters (which is called as Sinth Adi) in a line for the Tamil seppal song is more or less equal to 5 syllables of the Greek Sapphic songs. 


\section{Poetic Format}

The poetic format of Sapphic stanza should have four lines. The first three lines consist of 11 syllables each and the last line has five syllables. Moreover, the last word of the poem is specially called as adonic. In this way the overall structure of the Sapphic stanza is as shown in the figure.

Figure 6. Format of the Sapphic Stanza
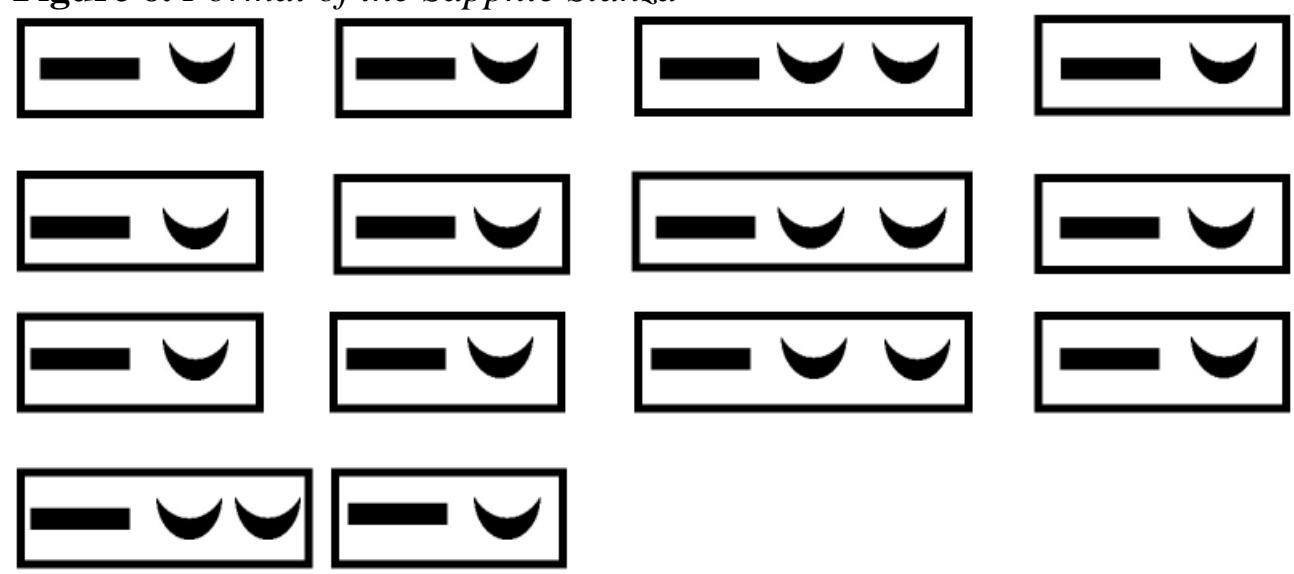

\section{$\underline{\text { Types in Seppal Songs Format }}$}

The Tamil Tholkappiam highlights many types of seppal songs based on the number of lines. ${ }^{17}$

Table 11. Types and Names of Seppal Songs

\begin{tabular}{|l|c|c|}
\hline S. No. & Line Restriction & Name \\
\hline 1 & Two line format & Kural Venba Seppal songs \\
\hline 2 & Three line format & Sinthial Venba Seppal songs \\
\hline 3 & Four line format & Neresai Venba Seppal songs \\
\hline 4 & Four line format & Innesai Venba Seppal songs \\
\hline 5 & More than four lines and up to 12 lines & Pala Thodai Venba Seppal songs \\
\hline 6 & More than 12 lines & Kali Venba Seppal songs \\
\hline
\end{tabular}

In all these types of format, the end line should be shorter than all the remaining lines. Here the end word should be only either two-syllabic or mono syllabic. These have special names such as Naal, Malar, Kasu and Perapphu.

There are two sub-categories in four line type format. If the fourth syllable of the third line is separated it is called as 'Neiresai Venba Seppal songs', and if not it is called as 'Innesai Venba Seppal songs'. Here, 'Innesai' in Tamil means 'sweet music'. Thus the type 4 format of the seppal song belongs to Innesai Venba Seppal song which is exactly the same as in the Greek Sapphic songs.

\footnotetext{
${ }^{17}$ Tholkappiam, seiyulial, 1375
} 


\section{Rhythmic of the Poem}

The Tamil Tholkappiam defines the several types of rhythmic sounds like 'Agaval, Thullal and Seppal', which are related with the poems. The sound of 'Agaval rhythmic' is related with communication of one person to many persons like that of orator's speech. 'Thullal music' sound is a jumping music related with joy. Finally the 'Seppal music' sound is related with the conversation of one person to another very slowly and secretly like that of expression of love. The poem which has a particular type of grammatical structure of syllables, word and sequence formation will automatically create a type of music that is unique for that particular structure. Thus the grammatical structure of the Tamil seppal songs leads to the seppal music which is very appropriate to convey love. So, the meaning of the Greek word Sapphic itself denotes the name of the music of that structured poem Seppal, which is related with love.

\section{Conclusion}

The Sapphic song format is not very ordinary. Its structures are very rigid and not easily changeable. It is very difficult for the poets to make a Sapphic stanza song within the restricted structure. Poets of various languages tried their best in the making of Sapphic stanza. In the same way, Tamil language also has Seppal songs like that of Sapphic stanza. It also follows very strict rules and there are many types in it. One among them is very much closely related in its features of the structure like that of Sapphic stanza in the following ways.

1. Very strict poetic structure,

2. The using of trochee and dactyl,

3. Sequence of word formation,

4. Four line format,

5. The last line is shorter than other lines,

6. The last line has 5 Greek syllables or 7 - 9 Tamil letters,

7. Other lines having around 11 Greek syllables or $10-14$ Tamil letters,

8. The last word of the poem should not exceed two syllables,

9. The last word has special poetic name,

10.The format opted for love music.

In these ways, Sapphic songs coincide in its features with one type of Tamil seppal songs. In Tamil, this seppal song is a traditional poetic structure whereas Sapphic songs in Greek belongs to an individual. More than this, seppal songs found in Tholkappiam has a well defined grammar which belongs to the same ancient era.

The rules for the language were not evolved in a day. Many school of thoughts first arose and it discussed the rules of the language. Then the rules were finalised in the written form. The Tamil Tholkappiam also mentioned many schools of grammarians in its text. And Tholkappiam mentions that the related data for the formation of certain grammatical rules connected with foreign words 
were collected from twelve united states, ${ }^{18}$ and were placed in the assembly of the king Pandion for discussion. ${ }^{19}$

The Greek geographer also mentions about the assembled of twelve united states by the Greek Pandion king Theseus.

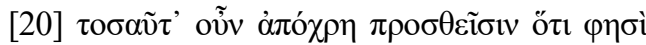

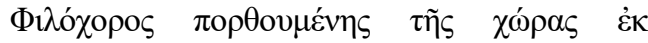

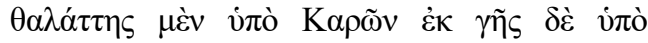

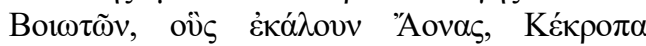

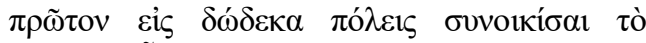

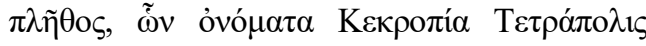

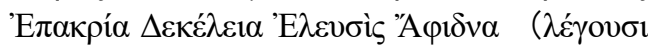

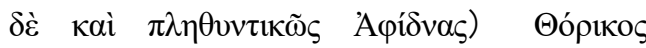

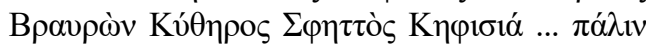

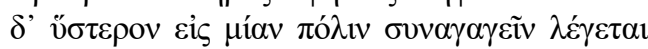

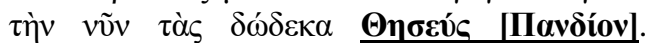

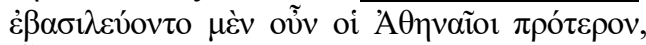

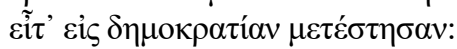

It will suffice then to add, that, according to Philochorus, when the country was devastated on the side of the sea by the Carians, and by land by the Bœotians, whom they called Aones, Cecrops first settled a large body of people in twelve cities, the names of which were Cecropia, Tetrapolis, Epacria, Deceleia, Eleusis, Aplhidnæ, (although some persons write it in the plural number, Aphidnæ,) Thoricus, Brauron, Cytherus, Sphettus, Cephisia [Phalerus]. Again, at a subsequent period, Theseus [Pandion] is said to have collected the inhabitants of the twelve cities into one, the present city. ${ }^{20}$

The following reference relates the Pandion kings with Greek and Tamil land.

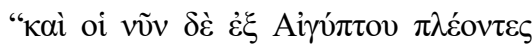

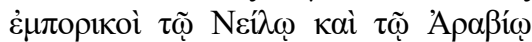

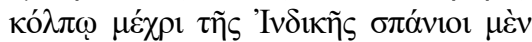

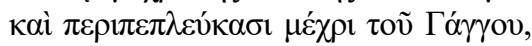

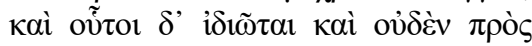

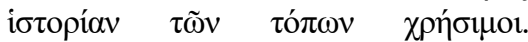

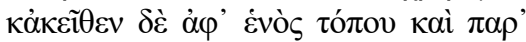

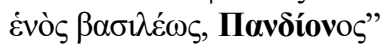

As for the merchants who now sail from Aegypt by the Nile and the Arabian Gulf as far as India, only a small number have sailed as far as the Ganges; and even these are merely private citizens and of no use as regards the history of the places they have seen. But from India, from one place and from one king, I mean Pandion, .... there came... and the Indian sophist who burnt himself up at Athens, as Calanus ${ }^{21}$

An ancient Greek work called 'Peripules of the Eritheranian Sea' refers that they had a kingdom in Tamil Nadu, India and the Greeks were trade with them.

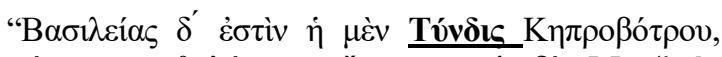

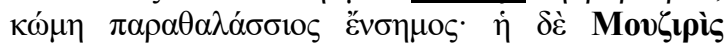

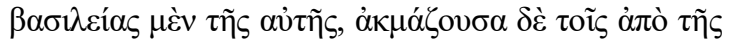

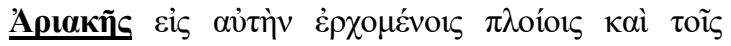

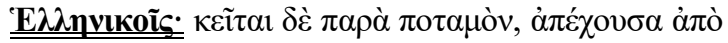

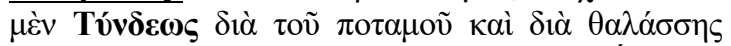

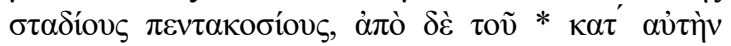

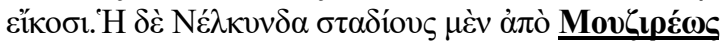

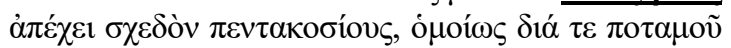

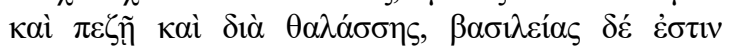

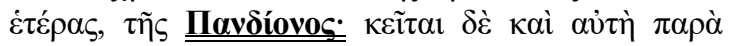

\footnotetext{
${ }^{18}$ Tholkappiam, echchaviayal, 882

${ }^{19}$ Tholkappiam, Phayiram

${ }^{20}$ Sec. 20, Chap. I, Book IX, Strab.

${ }^{21}$ Sec.15, Chap. I, Book IV, Strab.
}

Tyndis is of the Kingdom of Cerobothra; it is a village in plain sight by the sea. Muziris, of the same Kingdom, abounds in ships sent there with cargoes from Arabia, and by the Greeks; it is located on a river, distant from Tyndis by river and sea five hundred stadia, and up the river from the shore twenty stadia. Nelcynda is distant from Muziris by river and sea about five hundred stadia, and is of another Kingdom, the Pandion. This place also is 


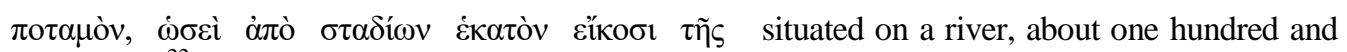
$\theta \alpha \lambda \alpha ́ \sigma \sigma \eta \varsigma^{, 22}$ twenty stadia from the sea.

Figure 7. Tamil Nadu as Mentioned in the Greek Literature

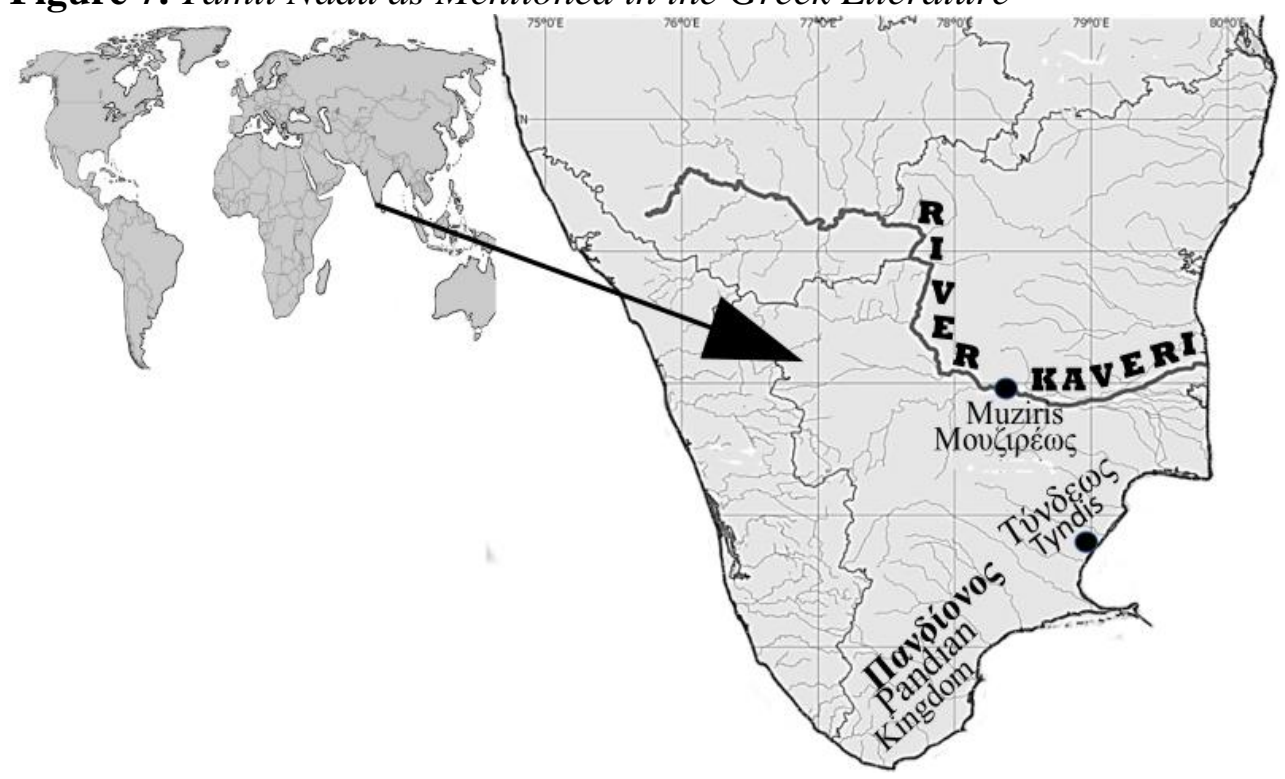

Thus the king Pandion is mentioned in both the Greek and the Tamil sources. More than that this Pandion was authorised for developing the grammar of Tamil seppal songs and organising the grammar book Tholkappiam. So, the possibility might be either during the period of Dionysus as mentioned by the Greek Geographer Strabo or during the reign of Pandion the format of the Tamil seppal song might be introduced from Tamil Nadu to Greek land. In this way, the strictly organised structure of the Greek Sapphic songs has a base in the Tamil grammar book Tholkappiam.

\section{Areas of Further Research}

There are so many opportunities for further research in this field. For example let us take a Sappho song.

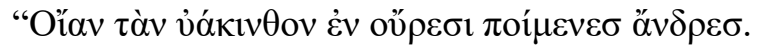

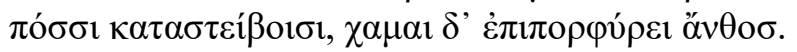

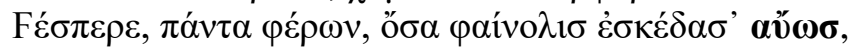

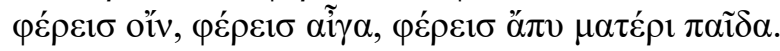

The meaning is as follows.

"O'er the hills the heedless shepherd,

Heavy footed, plods his way;

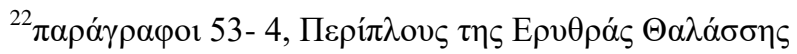


Crushed behind him lies the larkspur,

Soon empurpling in decay.

Hail, gentle Evening, that brings back

All things that bright morning hath beguiled.

Thou brings the lamb, thou brings the kid,

And to its mother, her drowsy child." 23

Here the meaning of $\alpha \tilde{v} \omega \sigma$ is discussed in the "Etymologicon Magnum," and the meaning be assumed as "dawn", because in no other place it occurs in the Greek, whereas in Tamil the word 'Aawos' means the animal which gives milk. This meaning that is found in Tamil also perfectly fits in the context of the Greek poem which proves that the assumed meaning 'dawn' has no base or root. So there are lot of opportunities for further research in this field.

\section{References}

Casson Lionel (1989) The Periplus Maris Erythraei: Text With Introduction, Translation, and Commentary. Princeton University Press, Princeton.

Halliwell Stephen (1986) Aristotle's Poetics. Chapel Hill.

Hugh G Evelyn White (1914) Hesiod. The Homeric Hymns and Homerica. Cambridge, MA., Harvard University Press, London, William Heinemann Ltd.

Hugh Tredennick (1989) Aristotle. Aristotle in 23 Volumes, Vols.17, 18. Cambridge, MA, Harvard University Press.

Marindin GE (1890) Aristoxenus Rhythmica, A Dictionary of Greek and Roman Antiquities. William Smith, LLD, William Wayte.

Jones H L (1924) Strabo. The Geography of Strabo. Cambridge, Mass: Harvard University Press.

$\mathrm{Sa} \mathrm{Ve} \mathrm{Su}$ (2007) Tamil Grammar Books. India: Tamil Virtual University.

Yopie Prins (2019) Sapphic Stanza - How Can We Read The Rhythm. New York: Critical Rhythm, Fordham University Press.

\footnotetext{
${ }^{23} 91,92$ - Sappho songs, [Quoted by Demetrius].
} 
